Kohl: a Journal for Body and Gender Research

Vol. 2, No. 1 (Summer 2016)

\title{
Beyond the Logic of State Protection: Feminist Self-Defense in Cairo after the January 25 Revolution
}

\author{
Susana Galán
}

\begin{abstract}
:
In the aftermath of the January 25 Revolution, self-defense tactics became popular against the fear of disorder and the increase of public sexual violence in Cairo. In this article, I examine a number of examples of self-defense invoked by public and private actors after the 2011 Revolution, and differentiate between two types of practices. The first, articulated around the right of legitimate self-defense recognized in the Egyptian penal code, aim to maintain or to restore the established order through the identification of an Other that embodies a threat to the self, property or community. In contrast to this, radical modes of selfdefense endeavor to subvert the given order by disrupting the gendered logic of masculinist and state protection and promoting horizontal relations of care and solidarity. Drawing on data generated through interviews with members of the initiative OpAntiSH and the collective WenDo, this article explores the importance of strategies and communities of autonomous self-defense in Egypt in relation to legal and policy measures adopted against sexual harassment by El-Sisi's regime since 2014.
\end{abstract}




\section{Introduction: Tales of Self-Defense}

In 2010, film director Mohamed Diab imagined in his movie 678 what would happen in Cairo if women stopped tolerating sexual harassment on the streets and in public transportation and, instead, decided to respond to these intrusions with violence. In a memorable scene, one of the main characters of the film, a woman named Fayza, boards the usually overcrowded bus where she is customarily groped, only to find a most unusual picture: bus passengers respectfully aligned, men on one side and women on the other, keeping their distance. "What's up with the men today?," shouts a woman in the bus, unaware of the stabbings that fill the headlines of the morning newspapers. Diab presents the question of self-defense as a desperate measure to an unbearable situation that brings women to the brink of insanity. While Fayza has to endure sexual harassment on an everyday basis, another central character, named Seba, turns to selfdefense after suffering a collective sexual assault during the celebrations for a soccer victory of Egypt's national team. The intractability of this violation distances Seba from her husband, who is unable to deal with his wife's pain: after witnessing his wife's public defilement, he is plagued by guilt and shame for having failed to fulfill his role as a protector.

As a resolution to this political fiction, Diab proposes what he intends to be a happy end. The police detective investigating the stabbings decides to pardon the women after his own wife dies in labor and leaves him without the much-desired male heir. Instead, the officer's newborn girl seemingly opens his eyes to the plight of Egyptian women. In the concluding scene, the third main character, named Nelly, appears in court, pressured by her future in-laws to withdraw a lawsuit against the man who grabbed her from a van while she was walking home. As the judge asks her to confirm her lawyer's request to drop the sexual harassment charges, her fiancé vocally opposes her withdrawal and encourages Nelly to pursue the lawsuit. The film ends with a reference to the conviction of the harasser and the criminalization of sexual harassment in Egypt, in a development that echoes the real story of Noha Rushdi, the woman who won the first sexual harassment case in Egypt in 2009. ${ }^{1}$ Within this narrative, the state-embodied in the figure of the police detective and the judge-is figured as the new protector of women in a context in which traditional forms of masculinist protection are no longer deemed effective. It is therefore with legal and policy change-and the necessary support of men-that Diab forecloses the possibility of women's autonomous self-defense and proposes a more conservative solution to public sexual harassment.

The question of self-defense has found a renewed relevance after the January 25 Revolution of 2011, with the increase and escalation of public sexual harassment and assaults in protests, and in public places more generally. In the days and years that followed the overthrow of Hosni Mubarak, collective sexual assaults perpetrated by large groups of men became a common occurrence in and around Tahrir square during mass demonstrations (El Nadeem et al. 2013; FIDH et al. 2014). Over this period of time, sexual harassment thrived on the streets and in public transportation (El Deeb 2013; Fahmy et al. 2014). In view of the state's failure to identify the perpetrators and hold them accountable for these violations, human and

1 The criminalization of sexual harassment, however, did not materialize until June of 2014 , as I discuss later in the essay. For a reflection on Noha Rushdi's case, see Amar 2011 and Abdelmonem 2015. 
women's rights groups accused power holders of complicity with this violence (El-Nadeem et al. 2013). In response to the pervasiveness of public sexual harassment and assault, a multiplicity of initiatives spontaneously appeared to prevent and stop these attacks on the ground.

Drawing on fieldwork research conducted in Cairo between September of 2014 and June of 2015, as well as on secondary sources discussing self-defense in Egypt, this article examines practices, strategies, and communities of self-defense that have emerged in the Egyptian capital, mostly after 2011.2 In my analysis, I differentiate between two forms of self-defense: the first section focuses on what I describe as "conservative" modes of self-defense. Under this rubric, I regard claims to the right of self-defense articulated by public and private actors in the name of security and the maintenance of order. I argue that these expressions of self-defense operate through the construction of an Other as the embodiment of chaos, privileging the restoration of order in the aftermath of the January 25 Revolution. The second section explores feminist self-defense, an expression of what I call "radical" modes of self-defense. ${ }^{3}$ Through interviews with members of the group Operation Anti-Sexual Harassment/Assault (OpAntiSH) and the collective WenDo, I examine the manifold ways through which these initiatives have challenged the logics of masculinist and state protection that underscore gender relations in Egypt. In the conclusion, I discuss the importance of feminist self-defense against public sexual violence in light of the recent legal and policy measures adopted by Abdel-Fattah El-Sisi's regime to criminalize sexual harassment.

\section{Fear of Disorder and Self-Defense in Egypt}

Self-defense became a popular tactic in the aftermath of the January 25 Revolution, albeit not necessarily in emancipatory ways. Certainly, the most disturbing example of the invocation of self-defense as a justification for the use of violence was General El-Sisi's statement, on June 26, 2011, that the military conducted virginity tests on women protesters "in self-defense against potential rape allegations" (Borkan 2011). This declaration was part of a broader public campaign to discredit revolutionary activists during the

2 My fieldwork research consisted of ethnographic observations and in-depth qualitative interviews. I conducted participant observation of activities organized by associations and groups working against public sexual harassment and assault, among them WenDo Egypt. In the course of my research, I attended three basic selfdefense courses organized by this initiative as well as a number of other info events addressed to a wide audience of women and girls. During my stay, I interviewed key members of groups organizing against public sexual violence. All the interviews were conducted in English and audio-recorded. For this article, I use material from my interviews with WenDo trainers and with former volunteers of OpAntiSH, as well as with Egyptian and foreign women living in the suburbs of 6th of October City and New Cairo. For the entirety of my fieldwork, I was a Research Fellow at the Cynthia Nelson Institute for Gender and Women's Studies (IGWS) of the American University in Cairo (AUC), under the direction of Professor Helen Rizzo. My research proposal received expedited IRB approval from both AUC and Rutgers University.

3 By "radical" I mean that these expressions of self-defense directly or indirectly advocate fundamental changes in existing social relations and structures. "Conservative" modes of self-defense, on the contrary, reproduce existing social relations and structures, and thereby contribute to consolidate them. I consider these two categories as ideal models. The examples that I discuss in the article are close to one or the other model, but do not necessarily fit their characterization perfectly. 
military rule that followed Mubarak's ouster on February 11, 2011 (Hafez 2014: 24). Through a discourse that mobilized patriarchal family values and morality codes, the Supreme Council of the Armed Forces (SCAF) aimed to regain control over public space after the revolution by casting women protesters as "sexually promiscuous," thus legitimizing the use of sexual violence against them (ibid.: 27).

The projects of self-defense that appeared all over the country during the 18 revolutionary days (January 25 through February 11, 2011) operated under more ambivalent gender regimes. On January 29, 2011, several thousand prisoners escaped from Wadi el-Natrun and three other jails (Fayed and Saleh 2011). Coupled with the withdrawal of the police from the streets, these events generated a wide range of rumors about the presence of armed gangs of criminals and looters around Cairo (Saleh 2011; Tisdall 2011). In response to these perceived threats, practices of collective self-defense rapidly emerged. In the gated community of City View, in the 6th of October suburb of Cairo, male residents and security personnel blocked the gates with vehicles and organized themselves in day and night shifts to guard the compound from outsiders. "We were not aware of the quantity of arms that people possessed," an Egyptian resident told me (interview May 23, 2015). Recalling the uncertainty of those days, she added that they were "lucky" that there was a former army sniper among the residents who watched the empty land around during the nights, crouched atop the highest peak of the compound with his sniper rifle with night vision scope (ibid.). ${ }^{4}$

Initiatives of collective self-defense were not confined to the affluent areas, but arose all over Cairo. In many neighborhoods, "popular committees" (sing. lagna sha 'biyya) made up of mostly young men were responsible for the protection of the area (Reuters 2011). Some of these popular committees became more than just neighborhood watches and, after the 18 revolutionary days, continued to organize at the local level for community development and reform (Mossallam 2011; El-Meehy 2015). ${ }^{5}$ Yet, most of them were constituted solely to fill the security void, as a temporary solution to maintain order in times of disorder, and disappeared with the return of the police. While these committees were active, their composition mirrored the gendered dynamics that position men as protectors and women as in need of protection in times of crisis, and their ways of organizing often mimicked police procedures of surveillance and control.

Increased perceptions of insecurity in public places led to heightened fear of sexual violence among women. As a result, the aftermath of the January 25 Revolution saw the popularization of personal protective devices and the multiplication of self-defense courses for women, particularly in wealthy neighborhoods. As a foreign resident in the gated community of Katameya Heights confided to me, she always kept a taser in her car and carried it whenever she ventured into the city on her own, not "out of

4 While fear of crime and urban disorder among the upper classes predate the January 25 Revolution and underlie many wealthy Egyptians' decision to move to the securitized residential compounds that have mushroomed around Cairo since the 1990s (Kuppinger 2004: 44), these anxieties grew exponentially after 2011. For a discussion of gated communities in Egypt, see also Mitchell 1999.

5 A detailed exploration of these initiatives is beyond the scope of this article. It is important to note, however, that some popular committees developed autonomous structures of economic and medical support and mechanisms of political accountability that contributed to transform their communities after 2011. These cases do not fit the "conservative" mode of self-defense model that I discuss in this section. 
fear" but as "a precaution" (interview May 3, 2015). As Lachenal (2014: 58) notes in her ethnography of self-defense training for upper-class women in Cairo following the revolution, feelings of vulnerability among women have opened "new market opportunities related to personal security." Significantly, in the courses she describes, women are often identified as wives and mothers, a position that subsumes their need for protection to their responsibility to protect those under their care.

Yet, examples of women's self-defense existed in Egypt before the January 25 Revolution. Already in 2009, probably following the Eid al-Fitr collective sexual assaults of 2008 , there were reports of women learning how to fight back against public harassment in martial arts dojos (Fraser 2009). ${ }^{6}$ However, unlike the women-only courses that I describe in the next section, these were mix-gendered classes where women exercised karate kicks and punches under the guidance of a male instructor. Another group of women practicing self-defense in Cairo around the same time were the female employees of the private security company Falcon (Wedeman 2009). Trained to act as bodyguards for prominent Egyptian and foreign women, nowadays these "lady guards" also conduct identity checks and bag searches of female students in the gates of Cairo University. This increased securitization is part of a set of measures adopted by ElSisi's regime in university campuses to stifle political dissent against the military coup that deposed Mohamed Morsi in July of 2013 (Khorshid 2014).

Whether as collective strategies for maintaining order, as individualistic projects of self-protection, or to fulfill the burgeoning demands of a neoliberal security market, the examples mentioned above have two elements in common. The first is an understanding of self-defense as a personal prerogative according to which subjects are entitled to exert violence in defense of themselves, their property, and kin. The right of legitimate self-defense (haqq al-difā ' al-shar' $\bar{l}$ 'an al-nafs) is recognized in the Egyptian penal code of 1937, which stipulates in Article 245 that "no punishment befalls one who kills or injures another in lawful self-defense, defense of property, or defense of another person's life or property" (Reza 2011: 191). ${ }^{7}$ Importantly, this right is restricted by two clauses: Article 247 negates the right of self-defense when subjects have recourse to law enforcement protection, and Article 248 prohibits resistance against authority in the name of self-defense "even if [law enforcement officers] exceed the scope of their duties" (ibid.: 192). By means of these limiting provisions, the penal code signals the subordination of the right of self-defense to the state's monopoly of violence.

The notion of self-defense enshrined in the penal code and reflected in the examples discussed above is perfectly encapsulated in the promotional material of the "Protection Academy" (Image 1). This self-defense program is advertised in the gated community of Katameya Heights, one of the most luxurious compounds of the desert suburb of New Cairo. Interpellating a masculine subject in his role as the protector of his family, the poster reads "Do you want to be able to protect yourself? Do you want to be able to protect your

6 During the celebration of this religious holiday, about hundred young men sexually assaulted women in the neighborhood of Mohandiseen (Leila 2008).

7 The principle of legitimate self-defense was already recognized in the 1883 and the 1904 Egyptian penal codes, both of them modeled along Napoleonic lines (Grandmoulin 1908: 386). 
wife and children? Do you want your wife to be able to protect herself and her children? ... Do you really want to [be able to] protect your car and deal with outlaws?" These questions, written both in Arabic and English, figure prominently amid an aggressive imagery dominated by a closed fist punching forward and a series of figures that represent an imagined evolution from ape to fighter.

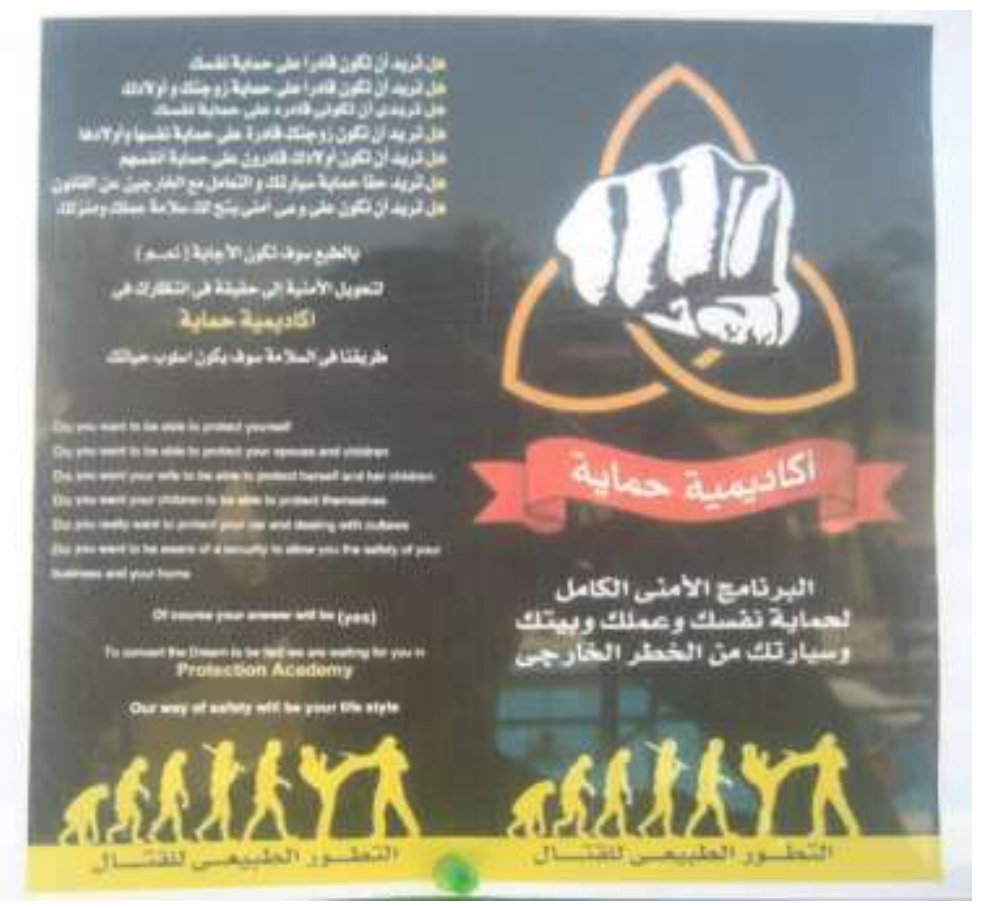

Image 1: Protection Academy in Katameya Heights. Picture by the author.

The second element that these different expressions of self-defense share is the identification of an Other-the "outlaws" in the Protection Academy poster-that poses a danger to the self, property, and, by extension, the community. In Strange Encounters, Ahmed (2000: 3) argues that the figure of the stranger is produced "not as that which we fail to recognise, but as that which we have already recognised as 'a stranger."' According to this author, the discourse of stranger danger creates the figure of the stranger as some-body that threatens the "purified space of the community" by virtue of its mere presence, and that needs to be expelled for the protection of this common space of belonging (ibid.: 22). For Ahmed, the aspirational moral and social well-being articulated by the community-and enforced by vigilante groups such as Neighborhood Watch-is nothing but a proxy for the maintenance of value and the protection of property in these spaces (ibid.: 27). Within this context, perceptions of safety and risk are mediated by "interpretations of race, class, and visual appearance" (Koskela 2005: 262). These assessments are prompts used by individuals to discriminate between safe and unsafe strangers in everyday encounters in public space, and by communities to determine whose bodies are suspicious and, therefore, should be the target of surveillance and control. As Ahmed (2000: 25) remarks, certain-gendered, raced, and classed- 
bodies are considered inherently dangerous, as existing relationships of power "mark some others as stranger than other others." [my emphasis]

In Cairo, this Other has been imagined over the course of the last decades through different figures that coexist with each other. One is the sexual harasser (or mutaharrish): identified by early research and activism and popularized by the media as an unemployed, impoverished, young man who cannot afford to get married due to the worsening economic conditions in Egypt, he turns to ogling and groping as an escape valve for his sexual frustration and as a means to "symbolically reclaim [his] masculinity in public" (Peoples 2008: 3). ${ }^{8}$ By focusing on stranger harassment as the main threat to women's bodies and honor, this discourse has rendered invisible other-equally pervasive-forms of sexual violence against women that take place in the privacy of the home or the workplace, and are perpetrated by intimates and acquaintances. ${ }^{9}$ Moreover, the framing of this phenomenon as a problem of lax security by nongovernmental organizations (NGOs) has served to justify a heightened securitization of public space and the extension of police brutality against working-class young men (Amar 2011: 318). ${ }^{10}$

Another figure that feeds anxieties about disorder are the poor masses rising from the informal settlements (or 'ashwā'iyyāt) and disturbing the "peace of the middle class neighborhoods" (Karawya 2009: 100). ${ }^{11}$ This fear has been nourished since the mid-2000s by movies like Khaled Youssef's "Till Things Get Better" and exploited by media and state discourses before the January 25 Revolution. ${ }^{12}$ In particular, the infiltration of the informal community of Imbaba by the militant Islamist group al-Gamā 'a al-Islāmiyya in the

8 Scholarly research published in the late 2000s presented public sexual harassment in Egypt as a social phenomenon linked to economic and social transformations. In particular, Peoples (2008) explained the pervasiveness of street sexual harassment in Cairo as a result of the structural rise in unemployment, especially among young men, and the breakdown of the patriarchal family. Similarly, llahi (2009: 64) reflected widespread considerations of sexual harassment as the only outlet for increasing numbers of 'unmarriageable' young Egyptian men against frustration and sexual repression. These theses have been countered by empirical research that has consistently demonstrated that public sexual harassment is not linked to occupation, education or marital status (Hassan et al. 2008: 17; Fahmy et al. 2014: 34).

9 A report published by El Nadeem Center for Rehabilitation of Victims of Violence (2015: 3) with data from all the cases treated by the center between 2007 and 2014 revealed that most times "women are subjected to several types of violence at the same time." As the study reflects, the majority of the 162 clients in the sample were subjected to rape (marital rape in $20.6 \%$ of the cases), followed by sexual assault, sexual harassment, and others (ibid.: 12).

10 For example, as part of the campaign "Making Our Streets Safe for Everyone," launched in 2005, the Egyptian Center for Women's Rights (2009: 36-39) demanded the installation of surveillance cameras in public places and a larger deployment of police officers on the streets.

11 'Ashwā'iyyāt is the plural of 'ashwā'iyya (literally "random" or "haphazard"). According to official estimates, in 2008 44\% of the population of the urban Greater Cairo area lived in informal settlements (Sims 2010).

12 "Till Things Get Better" (2007) is one of the many aflām 'ashwā'iyyāt (movies whose 'heroes' are dwellers in the informal settlements) that proliferated in Egypt during the mid-2000s. Director Youssef presented the film as a "warning message for the whole society, government and people, that the 'ashwā' $\bar{l}$ quarters surrounding Cairo are occult bombs that may explode anytime" (cited in Karawya 2009: 60). Echoing these fears, between 2007 and 2008 newspapers commonly reported about riots organized by residents of the informal settlements (ibid.: 53). In this same period, state authorities started to consider these communities as an "urban pathology" and a security threat (Ismail 2006: 66). 
1990s contributed to the formation of a discourse that marked 'ashwā'iyyāt as "centers of lawlessness, extremism, crime and poverty" (Bayat and Denis 2000: 197).

Finally, and closely related to these quarters, the figure of the thug (or balțagi) has historically represented the social and political Other that endangers social harmony. ${ }^{13}$ Considered "social terrorist[s]" and a threat to national security in the 1990s (Ismail 2006: 122), in the 2000s the balțagiyya became a valuable tool of the police, who hired them as informants and to terrorize protesters (Amar 2011: 308). A notorious example of this collaboration occurred on May 25, 2005 (known as Black Wednesday), when thugs affiliated with Mubarak's National Democratic Party (NDP) attacked a protest organized by the opposition movement Kefaya and sexually assaulted women activists. ${ }^{14}$ With the advent of the January 25 Revolution, the balțagiyya became a "collective and direct threat" as the police withdrew from the streets (Ghannam 2012: 34). During the 18 revolutionary days, the term balțagiyya was mostly used to refer to state-hired thugs who attacked the demonstrators in Tahrir square, but it has been mobilized by different actors (including the SCAF) afterwards to discredit their opponents as a menace to the community (ibid.: 35 , note 16).

Conservative modes of self-defense visualize one of these figures-or a combination of them-as the reason that justifies their need for protection. A case in point are the self-defense courses described by Lachenal (2014: 70), where the instructor encourages women participants to picture themselves in front of a balțagi and to project all their strength to fight this terrifying enemy. In their narratives, the balțagi is figured as a "dirty" and "badly dressed" man with "scars on his face" who "commits crimes for money" (ibid.). This characterization conveys marked class differences between the upper-class trainees and their imagined harasser, and reveals deep-seated anxieties about invasion and contamination of their bodies and neighborhoods in the aftermath of the January 25 Revolution. Yet, alongside these forms of selfdefense that revolve around the identification of-and mobilization against-an Other, more radical modes of self-defense have emerged in Cairo after 2011.

\section{Feminist Self-Defense against Public Sexual Violence}

On January 25, 2013, on the second anniversary of the 2011 Revolution, nineteen women were subjected to collective sexual assaults in Tahrir square and its vicinities (El Nadeem et al. 2013). These attacks represented an escalation of the "circles of hell" that had proliferated in protests since June of 2012 (ibid.;

13 According to Ghannam (2012: 34), the term balțagi traditionally denoted a man who "use[d] violence to impose his own will on others and to further his personal interests." This notion was mobilized by the Egyptian government in the late 1980s and early 1990s to refer to Islamist leaders and, since the mid-1990s, to label young men in the 'ashwā 'iyyāt (Ismail 2006: 140). In this context, Law 6 on 'thuggery' (balțaga) was passed in 1998 as part of the state's attempt to expand its security powers and institute order and discipline in the informal settlements (ibid.: xlv).

14 The public sexual assaults suffered by women protesters were denounced in activists' blogs. See, for example, http://wa7damasrya.blogspot.com/2005/05/blog-post_25.html (in Arabic) and http://tinkerthoughts.blogspot.com/2005/05/el-nas-el-soghayara.html. 
FIDH et al. 2014). On this occasion, for the first time, several women were injured with blades and other weapons (EIPR 2013). In response to these attacks, on February 6, 2013, women marched in downtown Cairo brandishing kitchen knives in the air and holding signs that threatened physical retaliation against the perpetrators (Image 2). On February 12, 2013, the online group The Uprising of Women in the Arab World called for a Global Protest against Sexual Terrorism to condemn this violence. ${ }^{15}$ In preparation for this event, cartoonist Doaa Eladl shared online an illustration that represented Egyptian singer Umm Kulthum holding a knife with the caption "Patience has Limits." Eladl's drawing circulated on Twitter and was later reproduced in banners internationally, popularizing self-defense narratives in Egypt and beyond.

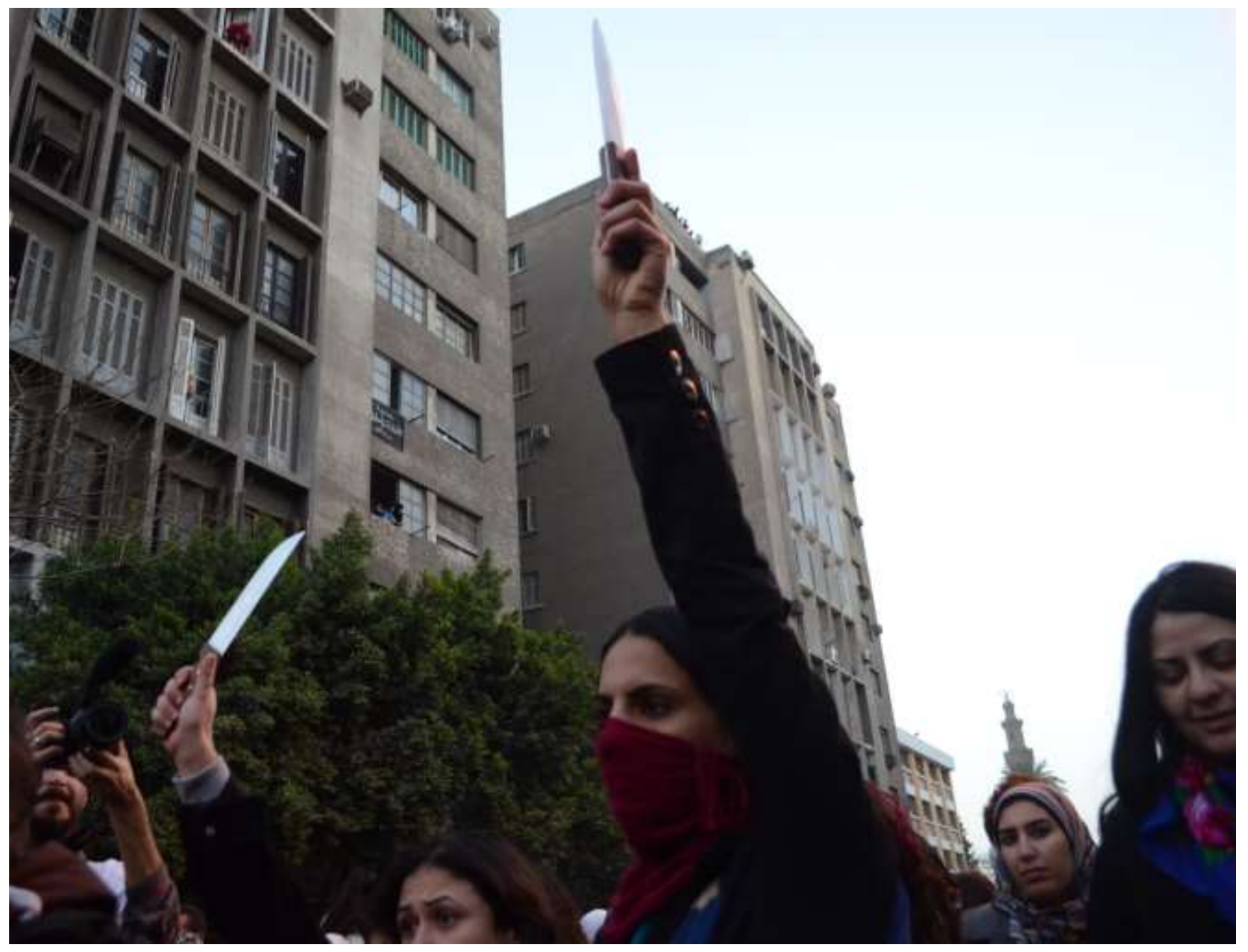

Image 2: Protest against the collective sexual assaults on the second anniversary of the January $25^{\text {th }}$ Revolution in Cairo, February 6, 2013. Picture by Haleem Elsha'rani. Reproduced with permission.

Yet, practices of collective self-defense were already present in Tahrir square by the end of 2012. On

15 For more information on the protest, see http://egyptianchronicles.blogspot.com/2013/02/globalprotestfeb12world-stands-with.html. See also https://twitter.com/search?q=\%23GlobalProtestFeb12. 
November 30, 2012, the initiative OpAntiSH was created in response to the sexual assault of nine women and girls next to the square. ${ }^{16}$ Their more immediate task was to prevent and stop-using violence when necessary -the collective sexual assaults that had become common in the area. For that purpose, they relied on a growing number of volunteers-young women and men-who, in many cases, were already active in protests or in groups tackling public sexual harassment and assaults, such as HarassMap or Nazra for Feminist Studies. As Dalia Abd El-Hameed, Gender and Women's Rights Officer at the Egyptian Initiative for Personal Rights (EIPR) and OpAntiSH volunteer remarks, OpAntiSH challenged the "stereotypical division of labor" according to which only men should participate in the intervention teams that rescued the assaulted women; from the beginning, the group refused to confine women volunteers to support and logistic tasks (interview March 16, 2015).

Self-defined as a "leftist-feminist-revolutionary" project, OpAntiSH rejected narratives that mobilized notions of honor to condemn public sexual violence or that, appealing to a masculinist logic of protection, asked men to treat activist women as their mothers, sisters, and daughters (ibid.). For journalist and OpAntiSH volunteer Yasmin El-Rifae, the collaborative work and the discussions that ensued from this effort in autonomous self-organization were "very transformative" and represented a learning experience for the hundreds of volunteers who participated in it, allowing for more critical engagements with the issue of public sexual violence in Egypt (interview March 28, 2015). By the time OpAntiSH stopped operating in Tahrir square, following the military coup of July 3,2013 , the group had put in place and into practice a very sophisticated system to combat violence against women in protests. Besides the teams that directly intervened to stop the assaults, there were safety teams that brought the survivors to a safe place or to the hospital, "midan teams" that distributed the hotline numbers in the square, scouts that monitored the area from rooftops and balconies, and an operation room that coordinated the teams. Moreover, they partnered with Nazra and El Nadeem Center to offer medical, legal, and psychological support to survivors.

Away from Tahrir square, other examples of feminist self-defense have appeared since 2013. In Cairo and other cities, the initiative WenDo Egypt offers self-defense workshops where women learn how to react with their facial expression, voice, and body language when someone crosses their boundaries, and develop physical techniques to defend themselves against an assailant. Taught by women and addressed to women only, the classroom provides a safe space in which participants of all ages, shapes, sizes, abilities, and fitness levels acquire practical skills they can use in threatening situations, while exploring the origin of their fears and their reluctance to react with verbal or physical self-defense to sexual intrusions. According to WenDo trainer Fatma Atef, women's lack of self-confidence and the perception that they are not "worthy enough to defend themselves" are behind this resistance (interview April 18, 2015).

In order to increase women's assertiveness, the course provides ample time for discussions where participants examine their presentation and behavior in public in a non-judgmental environment and, through role plays that recreate situations of harassment in public places, develop alternative performances with the support of the class. As WenDo trainer Kamilia El-Kady remarks, women have been taught to be

16 For more information, see https://www.facebook.com/opantish/?fref=ts and https://twitter.com/OpAntiSH. 
"good girl[s]," to walk looking down and to speak with a low voice (interview April 4, 2015). By staring a trainer-turned-harasser defiantly in the eye, shouting "kifāya" or "khalāṣ" ("enough," "stop"), or pushing "him" aside, trainees start to unlearn these habits by enacting movements that deviate from the repertoire of bodily dispositions dictated by the norms of hegemonic femininity. As a group, they learn together that they are able and have the right to defend themselves.

Unlike the self-defense courses described by Lachenal (2014), the target of WenDo is not necessarily a stranger lurking in the dark. As another WenDo trainer notes, many participants face some of the "most persistent" forms of harassment in the workplace, an aspect addressed indirectly in the course (interview April 27, 2015). ${ }^{17}$ According to Schirin Salem, founder of WenDo Egypt, the effect that the training has on women's self-confidence and self-esteem "trickles down to other spheres of life" and helps them to confront everyday situations of harassment (interview May 19, 2015). Similarly, for El-Kady, WenDo is "a lifestyle," and can be used as a way of enforcing emotional and physical boundaries to protect oneself from abuse by strangers, acquaintances, or intimates.

One of the aspects that emerged in all of my interviews with WenDo trainers was the impact that learning self-defense had on their lives: "I felt uncomfortable and shy when there is someone looking at me, like I'm walking naked," recalls WenDo trainer Yasmine Nassef, who now reports feeling "safe" in public places (interview April 2, 2015). In addition, Atef emphasizes how the training enhances a sense of solidarity among women, who feel compelled to "defend other girls" on the streets and other places. This multiplying effect has important consequences that may contribute to reduce the prevalence of public sexual violence in Egypt. As Salem argues, if women increasingly support each other to react against sexual harassment, men "will think twice" before harassing them.

The expressions of self-defense described above differ from the examples discussed in the previous section in that they aim to subvert the existing gender order. Importantly, radical modes of self-defense do not single out an Other as the embodiment of danger but address the structural foundations of public sexual violence. In both OpAntiSH and WenDo practices, self-defense appears as an act of disobedience and a rejection of the gendered logic of masculinist protection. Within this logic, men are situated in a position of dominance by virtue of their role as protectors of women and children, who occupy a "subordinate position of dependence and obedience" (Young 2003: 2). The rhetoric of protective masculinity is articulated around the differentiation between bad men or "selfish aggressors"-like the sexual harasser, the dweller of the 'ashwā 'iyyāt, and the balțagi discussed above-and good men or "selfless" protectors who defend the vulnerable ones against their threat (ibid.: 4; see also Griffin 1971: 30). Similarly, this narrative is built upon the distinction between "good women," who behave and therefore are worthy of protection, and "bad" or "fallen" women, who refuse to behave and therefore deserve to be publicly disciplined by means of sexual harassment or rape (Griffin 1971: 30; Peterson 1977: 361). Within this framework, public sexual violence serves as a constant reminder of women's vulnerability and need for protection, while fear of rape coerces women into compliance and contributes to maintaining gender

17 This trainer has preferred to remain anonymous. 
The logic of masculinist protection also operates at the level of the state. As historians have extensively documented, the control of women's conduct and sexuality is central to Egypt's process of state- and nation-building (Baron 2006; Kozma 2011). In the second half of the 19th century, the state's progressive encroachment upon areas previously managed by the family and the community, such as family honor, led to a displacement of traditional modes of social control by a newly formed medical, legal, and juridical bureaucracy that attempted to enforce a monopoly over the protection and punishment of women (Baron 2006: 2). The state's self-ascribed role as the "guardian and enforcer" of honor is enshrined in criminal law (ibid.: 15). ${ }^{18}$ In particular, Article 267 of the penal code prohibits "sexual intercourse with a female without her consent" (waqa 'a untha bighair ridaha), yet only recognizes rape as penile-vaginal penetration and does not apply when the woman is the perpetrators' wife (Reza 2011: 198; Sonbol 1996: 287). Article 268 and 269 cover any other type of non-consensual sexual contact, but its denomination as "indecent assault" (hatk 'ird, literally "violation of honor") discourages women from filing lawsuits due to the implication that the survivor has been "tarnished" (FIDH et al. 2014: 19). ${ }^{19}$ Moreover, the focus of these articles on consent places women's conduct and moral standing under scrutiny. Finally, while the penal code did not include any provision on sexual harassment until 2014, article 306 criminalizing "any offense against the modesty, honor or dignity of another" (khadsh hayā') was commonly used in these cases, thus strengthening the notion that sexual offenses jeopardize women's honor (Abdelmonem 2015: 26).

Reflecting on the "dimorphic morality" that establishes different behavioral codes for men and women in law and practice, Peterson (1977: 360) famously described the state as a male protection racket. As she argued, women become "victimized, unwilling clients" of state protection services due to their inability to rely on each other (ibid.: 368). As a crime syndicate of sorts, the state provides protection in exchange for certain restrictions on women's conduct. Women who refuse the state's protection bargain are held responsible for any violence encountered as a result of their self-assertion, including violence perpetrated by the state (Card 1996: 105). In this case, as in the masculinist forms of protection described above, the greatest threat to women is posed by their protector(s) (Stiehm 1982: 373). This relationship of dependence is exacerbated, as feminist scholars have noted, by hegemonic femininity's prescription of fragile, passive, and physically powerless bodies that can easily fall prey to sexual aggression (Griffin 1971: 33; McCaughey 1997: 37). The heightened need for protection that ensues leads to the acceptance of "more authoritarian and paternalistic state power" (Young 2003: 2).

18 The Egyptian penal code was promulgated in 1937, following the nominal independence of Egypt from the British in 1922. Modeled along Napoleonic lines, it was a major revision of the 1904 penal code, which in turn was an update of the French-inspired 1883 code (Reza 2011: 180; Baron 2006: 7). Unlike the Sultanic Code of 1855, the new regulations criminalized rape instead of premarital defloration (Kozma 2011: 120). Paradoxically, this development had a detrimental effect on women, who were no longer allowed to bring cases to court, as it was the case before (ibid.: 8). In the new context, the police played a central role in the investigation of rape cases, thus acting as a "buffer" between women and the judicial system (Sonbol 1997: 230). As a result, many rape cases were simply dismissed by the police, a situation that still persists today (ibid.).

19 Because of the limited definition of rape in Article 267, anal and oral rape as well as rape with fingers or objects have fallen under the purview of Article 268 (FIDH et al. 2014: 38). 
This protection bargain is manifest in El-Sisi's recent adoption of a series of legal and policy measures against sexual harassment that co-opt-without recognizing-decades of activism against public sexual violence. Among these are the activation of a unit responsible for monitoring violence against women, the amendment of the penal code in June of 2014 to criminalize sexual harassment, and the creation of an anti-harassment police force made up of female police officers (Ahram Online 2014; Hassanein 2014). A National Strategy for the Elimination of Violence Against Women-drafted by the official National Council for Women-was proudly presented in May of 2015 as the state's integrated approach to combat violence against women in the public and private sphere (NCW 2015). While addressing an important and urgent topic, the National Strategy maintains a limited definition of rape that does not include rape with fingers and objects, nor anal and oral rape regardless of gender, and continues to use a "morally charged language" linked to women's honor, particularly with regard to sexual assault, still referred to as hatk ird (EIPR 2015; see also Nazra for Feminist Studies 2015). Moreover, the emphasis on criminalization leaves the handling of this sensitive issue to the discretion of a police force known for its use of excessive violence (and infamous for harassing women while in service). It is precisely the double standard discussed above that enables the regime to proclaim itself the protector of women while it intensifies the practice of sexual violence and torture against both male and female detainees in police stations (FIDH 2015). In what sounds like a repetition of the discourse articulated in 2011 to justify the virginity tests, El-Sisi builds on the rhetoric of "bad" men and "fallen" women to present himself as a benevolent patriarch and invoke his (and by extension, Egypt's) right of self-defense against the internal moral and political enemy in the name of security.

As a corrective to this situation, Stiehm (1982: 374) advocated for a society of defenders where "the roles of the protector and the protected cease to exist." In this line, I argue that radical modes of self-defense like those promoted by OpAntiSH and WenDo importantly contribute to dismantling the logic of masculinist and state protection and the norms of hegemonic femininity that are at the core of the state's complicity in the perpetuation of sexual violence against women. Through direct action and the creation of communities of solidarity, these initiatives transform women's experience of their bodies, public space, and their relationship with others and, in so doing, participate in the creation of horizontal structures of care that cut across familial and social ties. These autonomous ways of organizing represent a form of resistance to topdown approaches to public sexual violence privileged by the state. In this sense, these projects inscribe themselves within broader struggles of autonomous self-defense against state violence (Üstündağ 2015).

\section{Conclusion}

Despite 678's imaginative limitations, the film offers a prescient glimpse of the possibilities of collective selfdefense as a feminist project against public sexual violence in Egypt. When watching the movie, it is inevitable that one asks oneself: What would happen if Fayza, Seba, and Nelly insisted on physically countering public sexual harassment instead of yielding to the state's claim to the monopoly of violence? If they persisted on responding to these aggressions instead of relying on state agencies to respond on their 
behalf, how would that impact their lives and occupation of public space? If other women, or all women in Cairo for that matter, followed their lead and refused to endure and remain silent in the face of their own and other women's subjection to these everyday sexual intrusions, would public sexual violence subside? What effect would this collective refusal to comply with norms of femininity that position women as in need of protection have on masculinity, the security state, and recent neoliberal urban developments?

The aftermath of the January 25 Revolution has provided a unique ground for the exploration of these questions. Following the 18 days of uprisings and the disappearance of the police from public space, Egyptians reacted to the security void by adopting different strategies of self-protection. As I have discussed above, some of these initiatives (which I have termed conservative) were transitory responses to the absence of state authority, and lost their relevance as order was restored. Focused on repelling the potential invasion of an Other-variously imagined as a sexual harasser, an 'ashwā'iyyāt dweller or a balțagi-amid the revolutionary confusion, it is no surprise that proponents of these forms of self-defense were among the voices that welcomed the redeployment of the security forces and embraced El-Sisi's calls for a return to "normality" after the military coup of July of 2013.

Yet, the increase and exacerbation of public sexual harassment and assaults in protests and other public places also gave rise to other modes of self-defense (which I have described as radical) that challenged notions of female vulnerability and male protection, claimed women's right to public space, and-directly or indirectly - questioned the role of the state as the protector of women within a paternalistic model foregrounded in notions of female respectability and honor. Paradoxically, the retreat of the police from Tahrir square and the streets more generally provided these groups with an arena where they could enact autonomous forms of organization and, collectively, develop novel approaches for the prevention of and intervention against public sexual violence in Egypt. The reestablishment of "order" after El-Sisi's seizure of power has meant the closure of these spaces of social and political experimentation.

OpAntiSH decided to stop intervening in protests after the 2013 coup, as mass gatherings in Tahrir square acquired a pro-military character that clashed with the group's political convictions. Other organizations operating on the square left the area soon afterwards, conscious of the risk of police detention faced by their volunteers. Since 2014, the work of grassroots initiatives against public sexual harassment and assaults has become increasingly precarious following the regime's tightening of control over public space and its crackdown on NGOs (El Sirgany 2014; Kirkpatrick 2014). In particular, those still working on the streets face police harassment on a daily basis.

In this situation, the example of OpAntiSh and WenDo allows us to imagine ways of combating sexual harassment and assault in Egypt that move beyond increased criminalization and policing of public space. The deployment of OpAntiSH volunteers in Tahrir square between 2012 and 2013 and their autonomous organization of a system of response and comprehensive care to survivors of sexual violence constitute a model developed and tested through the collective engagement of hundreds of activists on the ground that, far from pretending to replace the state in its functions and responsibilities, has revealed its deficiencies in 
an attempt to transform it. Through the promotion of feminist self-defense, WenDo asserts that women's just claim to legal and judicial redress after a sexual assault does not preclude their even juster claim to resist victimization in the first place. The multiplication of their workshops in fitness, cultural, youth, and refugee centers contributes to the creation of networks of solidarity among women that crack open the contradictions of the paternalistic state and challenges discourses of stranger danger and construction of risk in public space. Through these past and present practices, OpAntiSH and WenDo prefigure and point the way towards futures where public sexual violence is increasingly challenged by the feminist praxis of organized communities. 
Kohl 2.1

\section{References}

Abdelmonem, Angie. "Reconceptualizing Sexual Harassment in Egypt: A Longitudinal Assessment of elTaharrush el-Ginsy in Arabic Online Forums and Anti-Sexual Harassment Activism." Kohl: a Journal for Body and Gender Research. 2015, 1(1): 23-41.

Ahmed, Sara. Strange Encounters: Embodied Others in Post-Coloniality. London and New York: Routledge, 2000.

Ahram Online. "President Mansour Leaves Office with a Legislative Bang." Ahram Online. 2014, June 5. Last Accessed $\quad$ February 2016. http://english.ahram.org.eg/NewsContent/1/64/103023/Egypt/Politics-/President-Mansour-leavesoffice-with-a-legislative.aspx.

Amar, Paul. "Turning the Gendered Politics of the Security State Inside Out?" International Feminist Journal of Politics. 2011, 13(3): 299-328.

Baron, Beth. "Women, Honour, and the State: Evidence from Egypt." Middle Eastern Studies. 2006, 42(1): 1-20.

Bayat, Asef, and Eric Denis. "Who is Afraid of 'Ashwaiyyat'? Urban Change and Politics in Egypt." Environment \& Urbanization. 2000, 12(2): 185-199.

Borkan, Brett. "Military Intelligence Head Says Virginity Tests Conducted Out of Self-Defense: Amnesty." Daily News Egypt. 2011, June 26. Last Accessed January 13, 2016. http://www.dailynewsegypt.com/2011/06/26/head-of-military-intelligence-confirms-virginity-testsconducted-out-of-self-defense.

Card, Claudia. The Unnatural Lottery: Character and Moral Luck. Philadelphia: Temple University Press, 1996.

Egyptian Center for Women's Rights. "Sexual Harassment in the Arab Region: Cultural Challenges and Legal Gaps. Findings from the Conference on Sexual Harassment as Social Violence and Its Effect on Women." 2009. Last Accessed February 4, 2016. http://egypt.unfpa.org//mages/Publication/2010_12/8655f498-85a0-434e-9396-bfa3b390f63e.pdf.

EIPR, Egyptian Initiative for Personal Rights. "A Confused Step in the Right Direction: Commentary on the National Strategy to Combat Violence against Women." 2015, June 23. Last Accessed February 4, 2016. http://eipr.org/en/pressrelease/2015/06/23/2411.

"Operation Anti-Sexual Harassment/Assault Condemns the Attacks on Women in Tahrir Square on Friday January 25th, the Failure of Political Groups to Secure the Square and Unprofessional Media Conduct." 2013, January 29. Last Accessed January 13, 2016. http://eipr.org/en/pressrelease/2013/01/29/1612.

Deeb, Bouthaina. "Study on Ways and Methods to Eliminate Sexual Harassment in Egypt." UN Women. 2013. Last Accessed March 22, 2016. http://harassmap.org/en/wpcontent/uploads/2014/02/287_Summaryreport_eng_low-1.pdf.

El-Meehy, Asya. "Egypt's Popular Committees: From Moments of Madness to NGO Dilemmas." Middle East Report. 2015, 265: 29-33.

El Nadeem Center for Rehabilitation of Victims of Violence. "Women and Sexual Violence: An Analytic Report of the Women's Project Files." 2015. Print. 
El Nadeem Center for Rehabilitation of Victims of Violence and Torture, Nazra for Feminist Studies, and New Woman Foundation. "Sexual Assault and Rape in Tahrir Square and its Vicinity: A Compendium of Sources 2011-2013." 2013. Last Accessed January 13, 2016. http://nazra.org/sites/nazra/files/attachments/compilation-_of_sexual-violence_testimonies_between_20111_2013_en.pdf.

El Sirgany, Sarah. "The Ongoing Campaign to Restrict Egypt's Public Space." Atlantic Council. 2014, September 11. Last Accessed March 26, 2016. http://www.atlanticcouncil.org/blogs/egyptsource/the-ongoing-campaign-to-restrict-egypt-s-publicspace.

Fahmy, Amel, Angie Abdelmonem, Enas Hamdy, Ahmed Badr, and Rasha Hassan. "Towards a Safer City - Sexual Harassment in Greater Cairo: Effectiveness of Crowdsourced Data." HarassMap. 2014. Last Accessed March 22, 2016. http://harassmap.org/en/wp-content/uploads/2013/03/Towards-ASafer-City_full-report_EN-.pdf.

Fayed, Shaimaa, and Yasmine Saleh. "Egypt in Crisis, Mubarak Meets Commanders." Reuters. 2011, January 30. Last Accessed April 26, 2016. http://www.reuters.com/article/idINIndia54514620110130.

FIDH. "Exposing State Hypocrisy: Sexual Violence by Security Forces in Egypt." 2015. Last Accessed February 4, 2016. https://www.fidh.org//MG/pdf/egypt_report.pdf.

FIDH, Nazra for Feminist Studies, New Woman Foundation, The Uprising of Women in the Arab World. "Egypt: Keeping Women Out." 2014. Last Accessed February 4, 2016. http://www.fidh.org/lMG/pdf/egypt_women_final_english.pdf.

Fraser, Christian. "Egyptian Women Learn to Fight Back." BBC News. 2009, March 18. Last Accessed January 13, 2016. http://news.bbc.co.uk/2/hi/middle_east/7936071.stm.

Ghannam, Farha. "Meanings and Feelings: Local Interpretations of the Use of Violence in the Egyptian Revolution." American Ethnologist. 2012, 39(1): 32-36.

Grandmoulin, J. Le droit pénal égyptien indigène t. 2. Cairo: Imprimerie Nationale, 1908.

Griffin, Susan. "Rape: The All-American Crime." Ramparts Magazine. 1971, 26-35.

Hafez, Sherine. "Bodies That Protest: The Girl in the Blue Bra, Sexuality, and State Violence in Revolutionary Egypt." Signs: Journal of Women in Culture and Society. 2014, 40(1): 20-28.

Hassan, Rasha, Nehad Aboul Qomsan, and Aliyaa Shoukry. "Clouds in Egypt's Sky: Sexual Harassment, From Verbal Harassment to Rape - A Sociological Study." 2008. Last Accessed April 26, 2016. http://egypt.unfpa.org//mages/Publication/2010_03/6eeeb05a-3040-42d2-9e1c-2bd2e1ac8cac.pdf.

Hassanein, Mohamed Abdu. "Egypt Deploys Female Anti-Harassment Police Unit." Asharq Al-Awsat. 2014, October 9. Last Accessed February 4, 2016. http://www.aawsat.net/2014/10/article55337339/egypt-deploys-female-anti-harassment-police-unit.

Ilahi, Nadia. "Gendered Contestations: An Analysis of Street Harassment in Cairo and its Implications for Women's Access to Public Spaces." Surfacing. 2009, 2(1): 56-69.

Ismail, Salwa. Political Life in Cairo's New Quarters. Minneapolis, MN: University of Minnesota Press, 2006. Karawya, Fayrouz El Sayed. "The Construction of Chaos: Cinematic Representations and Politics in Egypt in the 2000s." MA Thesis, Department of Sociology, Anthropology, Psychology, and Egyptology, The American University in Cairo, 2009. 
Kohl 2.1

Khorshid, Reem. "The Falcons on Campus." Mada Masr. 2014, October 13. Last Accessed January 13, 2016. http://www.madamasr.com/opinion/politics/falcons-campus.

Kirkpatrick, David D. "Human Rights Groups in Egypt Brace for Crackdown Under New Law." New York Times. 2014, December 26. Last Accessed March 26, 2016. http://www.nytimes.com/2014/12/27/world/middleeast/human-rights-groups-in-egypt-brace-forcrackdown-under-new-law.html?_r=0.

Koskela, Hille. "Urban Space in Plural: Elastic, Tamed, Suppressed." A Companion to Feminist Geography, edited by Nelson, Lise, and Joni Seager. Malden and Oxford: Blackwell Publishing, 2005. 257-270.

Kozma, Liat. Policing Egyptian Women: Sex, Law and Medicine in Khedival Egypt. Syracuse, NY: Syracuse University Press, 2011.

Kuppinger, Petra. "Exclusive Greenery: New Gated Communities in Cairo." City \& Society. 2004, 16(2): 3561.

Lachenal, Perrine. "Beauty, the Beast, and the Baseball Bat: Ethnography of Self-Defense Training for Upper-Class Women in Revolutionary Cairo (Egypt)." Comparative Sociology. 2014, 13: 58-77.

Leila, Reem. "Unsafe Streets." Al-Ahram Weekly. 2008, October 9-15. Last Accessed January 13, 2016. https://web.archive.org/web/20081012084224/http://weekly.ahram.org.eg/2008/917/eg6.htm.

McCaughey, Martha. Real Knockouts: The Physical Feminism of Women's Self-Defense. New York and London: New York University Press, 1997.

Mitchell, Timothy. "Dreamland: The Neoliberalism of Your Desires." Middle East Report. 1999, 210: 28-33.

Mossallam, Alia. "Popular Committees Continue the Revolution." Egypt Independent. 2011, June 18. Last Accessed January 13, 2016. http://www.egyptindependent.com/opinion/popular-committeescontinue-revolution.

Nazra for Feminist Studies. "The Relationship between Feminism and State Policies for the Elimination of Violence against Women: The National Strategy for the Elimination of Violence against Women as an Example." 2015, December 10. Last Accessed February 4, 2016. http://nazra.org/en/node/441.

NCW, National Council for Women. 2015. "Al-īstrātijīa al-wațanīa limukāfahat al- 'unf ḍidd al-mar'a 20152020" (National Strategy for the Elimination of Violence Against Women 2015-2020). Print.

Peoples, Fatima Mareah. "Street Harassment in Cairo: A Symptom of Disintegrating Social Structures." The African Anthropologist. 2008, 15(1\&2): 1-20.

Peterson, Susan Rae. "Coercion and Rape: The State as a Male Protection Racket." Feminism and Philosophy, edited by Mary Vetterling-Braggin, Frederick A. Elliston, and Jane English. Totowa, New Jersey: Rowman and Littlefield, 1977. 360-371.

Reuters. "Egypt Jail Break: 700 Prisoners Escape South of Cairo." The Huffington Post. 2011, January 29. Last Accessed January 13, 2016. http://www.huffingtonpost.com/2011/01/29/egypt-jail-break-700prisoners-escape_n_815872.html.

Reza, Sadiq. "Egypt." The Handbook of Comparative Criminal Law, edited by Kevin Jon Heller and Markus D. Dubber. Stanford, CA: Stanford University Press, 2011. 179-208.

Saleh, Heba. "Cairo Residents Fear of Security." Financial Times. 2011, January 30. Last Accessed January $\quad 13, \quad 2016 . \quad$ http://www.ft.com/cms/s/0/2e3152bc-2c5b-11e0-83bd00144feab49a.html\#axzz3f6lZ1ysx. 
Sims, David. Understanding Cairo: The Logic of a City Out of Control. Cairo and New York: The American University in Cairo Press, 2010.

Sonbol, Amira. "Rape and Law in Ottoman and Modern Egypt." Women in the Ottoman Empire: Middle Eastern Women in the Early Modern Era, edited by Madeline C. Zilfi. Leiden, New York, Köln: Brill, 1997. 214-231. . "Law and Gender Violence in Ottoman and Modern Egypt." Women, the Family, and Divorce Laws in Islamic History, edited by the author. Syracuse, NY: Syracuse University Press, 1996. 277-289.

Stiehm, Judith Hicks. "The Protected, the Protector, the Defender." Women's Studies International Forum. 1982, 5(3/4): 367-376.

Tisdall, Simon. "Egypt Protests: Cairo Prison Break Prompts Fear of Fundamentalism." The Guardian. 2011, January 30. Last Accessed January 13, 2016. http://www.theguardian.com/world/2011/jan/30/muslim-brotherhood-jail-escape-egypt.

Üstündağ, Nazan. "New Wars and Autonomous Self-Defense." Jadaliyya. 2015, November 18. Last Accessed February 3, 2016. http://www.jadaliyya.com/pages/index/23209/new-wars-andautonomous-self-defense.

Wedeman, Ben. "Martial-arts Trained 'Lady Guards' Latest Security Craze in Egypt." CNN. 2009, $\begin{array}{lllll}\text { December } 18 . & \text { Last } \quad \text { Accessed } & \end{array}$ http://edition.cnn.com/2009/WORLD/meast/12/18/egypt.female.bodyguards.

Young, Iris Marion. "The Logic of Masculinist Protection: Reflections on the Current Security State." Signs: Journal of Women in Culture and Society. 2003, 29(1): 1-25. 